\title{
ANALISIS KEBIJAKAN MONETER PADA AWAL PEMERINTAHAN ISLAM TERHADAP PEMBANGUNAN PEREKONOMIAN ISLAM
}

\author{
Hoirul Amri \\ Fakultas Agama Islam Universitas Muhammadiyah Palembang \\ Email : hoirulamri@yahoo.com
}

\begin{abstract}
ABSTRAK
"Penelitian ini bertujuan untuk mengetahui bagaimana kebijakan Moneter pada awal Pemerintahan Islam dalam Pembangunan Ekonomi Islam. Metodologi penelitian ini termasuk jenis penelitian pustaka (library research). Hasil penelitian menunjukkan bahwa peletakan dasar-dasar sistem keuangan Negara (Moneter) yang dilakukan oleh awal Pemerintahan Islam sangat signifikan, cemerlang dan spektakuler pada waktu itu sehingga Islam sebagai Agama dan Negara dapat berkembang pesat. dalam waktu yang relatif singkat. Kemudian pengelolaan sistem moneter pada awal Pemerintahan Islam diserahkan kepada lembaga Baitul Mal dan dampak kebijakan moneter terhadap ekonomi pada permulaan berdampak terhadap kenaikan Agregate Demand sekaligus Agregate Supply.
\end{abstract}

Kata Kunci : Moneter, Rasulullah SAW, Ekonomi Islam, Pemerintahan

\section{DASAR PEMIKIRAN}

Sejak awal dalam pemerintahan Islam, kebijakan moneter merupakan salah satu perangkat untuk mencapai tujuan syari'ah termasuk meningkatkan kesejahteraan dengan tetap menjaga keimanan, kehidupan intelektual, kekayaan dan kepemilikan (Huda at el., 2009: 154). Negara mempunyai hak untuk masuk dalam kehidupan ekonomi masyarakat demi melanjutkan kesejahteraan bersama dengan menjalankan kebajikan dan menghilangkan kerusakan al-amar bil ma'ruf al-nahiy al-munkar dengan pelarangan riba, mencegah penimbunan (ikhtikar), memerangi segala bentuk penipuan dalam transaksi dan mengatur transaksi perniagaan masyarakat (Sinn, 2000: 21).

Selain itu, sebagaimana dinyatakan Ibnu Taimiyah bahwa pemerintah merupakan institusi yang sangat dibutuhkan untuk mengatur segala urusan masyarakat. Bahkan agama tidak bisa ditegakkan tanpa negara (Muhammad, 2007: 96). Maka dalam konteks peran negara, landasan tersebut menghendaki pemerintah sebagai representasi dari negara mengambil keputusan secara bijak dalam pembangunan sosial ekonomi dan politik artinya dasar-dasar ekonomi yang bersifat pragmatis dan dapat merugikan banyak pihak harus dihindari. Hal ini diperkuat oleh Negara dan masyarakat 


\section{2 | Hoirul Amri Analisis Kebijakan Moneter pada Awal Pemerintahan Islam terhadap Pembangunan Perekonomian Islam}

mempunyai wewenang yang menyangkut aktivitas ekonomi yang diistilahkan dengann al-Amar bil al-ma'ruf dan Al-nahiy'an al-munkar (Shihab, 2007: 474).

Atas dasar prinsip ini, maka pengawasan terhadap harta benda dapat dibenarkan. Di lain segi, perlu digaris bawahi bahwa Islam dapat membenarkan segala macam tindakan pemerintah selama tindakan tersebut menunjang "kepentingan dan kemaslahatan masyarakat umum" dalam istilah hukum Islam dinamakan al-Masalih alMursalah. Kemaslahatan tersebut termasuk dalam bidang ekonomi dan moneter.

Menurut Chapra (2000: 134) kebijakan moneter akan berperan penting dalam membantu merealisasikan tujuan sistem ekonomi Islam. Dalam sebuah perekonomian negara Islam permintaan akan uang akan lahir terutama motif transaksi dan tindakan berjaga-jaga yang ditentukan oleh pendapatan uang dan distribusinya. Pada awal pemerintahan Islam, kedua mata uang tersebut diimpor dinar dari Romawi dan dirham dari Persia. Besarnya volume impor dinar dan dirham juga barang-barang komoditas lainnya tergantung pada volume komoditas yang diimpor dari kedua negara tersebut dan wilayah-wilayah lain yang berada di bawah pengaruhnya. Lazimnya uang yang akan diimpor jika permintaan uang (money demand) pada pasar internal mengalami kenaikan dan sebaliknya komoditas akan diimpor jika permintaan uang mengalami penurunan.

Maka dari itu, kebijakan pembangunan Islam sangat berorientasi untuk: meningkatkan tingkat spiritual masyarakat Islam dan meminimalisasi kerusakan moral dan korupsi; memenuhi kewajibannya untuk kesejahteraan ekonomi dalam batas-batas sumber daya yang tersedia; dan menjamin keadilan distributif dan memberantas praktik eksploitasi. Islam mengajarkan falsafah kesejahteraan yang unik, komprehensif dan konsisten dengan fitrah manusia. Sebuah doktirn yang melekat dan menyatu dalam kepribadian masyarakat (built-in in-doctrination). Kesejahteraan individu dalam masyarakat Islam terealisasi bila ada iklim yang cocok bagi: pelaksanaan nilai-nilai spiritual Islam secara keseluruhan untuk individu maupun masyarakat; pemenuhan kebutuhan pokok material manusia dengan cukup; dan menitikberatkan pada nilai-nilai moral (Nurnasrina, 2013: 226).

Keberhasilan tersebut tentu saja sangat menarik untuk diteliti ulang untuk mengetahui secara pasti implikasi kebijakan monter yang dibuat Nabi Muhammad SAW berhasil membawa berbagai perubahan (reform) terhadap struktur kehidupan masyarakat, ketimpangan berhasil dihapus, dan perubahan menyangkut keimanan 
(tauhid), moral (akhlak), politik dan keadilan sosial. Sehingga menghasilkan kesejahteraan pada masyarakat Madinah, sehingga Madinah terkenal dengan baldatun tayyibatul wa rabb al-ghafur.

Apalagi dalam konteks sekarang, terjadi kegagalan pembangunan ekonomi dimana-mana, ditandai dengan adanya kemiskinan masyarakat, eksploitasi kaum miskin oleh kaum kaya dan berkuasa, meningkatnya disparitas pada tingkat regional dan internasional tidak seimbangnya produksi dan konsumsi terhadap kebutuhan lingkungan, dan tidak rasionalnya pemanfaatan sumberdaya alam yang tidak dapat diperbaiki. Dari latar belakang di atas, maka penulis akan menelaah kebijakan moneter pada awal pemerintahan Islam. Konteks telaah dalam tulisan ini adalah "Analisis Kebijakan Moneter Pada Awal Pemerintahan Islam Terhadap Pembangunan Perekonomian Islam"

\section{PEMAHAMAN}

\section{A. Konsep Dasar Kebijakan Moneter}

Menurut kamus umum Bahasa Indonesia (t.t: 256) moneter diartikan sesuatu yang ada hubunganya dengan keuangan Negara atau masalah keuangan. Kebijakan moneter pada dasarnya adalah kebijakan yang digunakan oleh Pemerintah untuk mengatur jumlah uang yang beredar. Oleh karena itu, kontribusi kebijakan moneter terhadap stabilitas harga sangat penting untuk menekan tingkat inflasi. Pertumbuhan jumlah uang yang beredar sebaiknya mengikuti pertumbuhan ekonomi, sehingga secara tidak langsung dapat menekan tingkat pengangguran.

Kebijakan moneter pada dasarnya merupakan suatu kebijakan yang bertujuan untuk mencapai keseimbangan internal (pertumbuhan ekonomi yang tinggi, stabilitas harga, pemerataan pembangunan) dan keseimbangan eksternal (keseimbangan neraca pembayaran) serta tercapainya tujuan ekonomi makro, yakni menjaga stabilitas ekonomi yang dapat diukur dengan kesempatan kerja, kestabilan harga serta neraca pembayaran internasional yang seimbang.

Menurut Manan (1997: 214) mengemukakan kebijakan moneter adalah kebijakan yang seharusnya mengikuti tujuan-tujuan untuk mempertahankan stabilitas dalam nilai mata uang kesejahteraan ekonomi, kesempatan kerja sepenuhnya, pertumbuhan ekonomi yang optimum dan peningkatan keadilan bagi setiap orang. 


\section{4 | Hoirul Amri Analisis Kebijakan Moneter pada Awal Pemerintahan Islam terhadap Pembangunan Perekonomian Islam}

Sedangkan Boediono (1990: 96) menyatakan kebijkan moneter adalah tindakan pemerintah (atau bank sentral) untuk mempengaruhi situasi makro yang dilaksanakan melalui pasar uang. Ini difenisi umum, secara lebih khusus kebijakan moneter bisa diartikan sebagai tindakan makro Pemerintah (bank sentral) dengan cara mempengaruhi proses penciptaan uang.

Dari defenisi di atas, dapat diketahui bahwa melalui kebijakan moneter Pemerintah dapat mempertahankan, menambah atau mengurangi jumlah uang beredar dalam upaya mempertahankan kemampuan ekonomi untuk terus tumbuh sekaligus mengendalikan inflasi. Jika yang dilakukan adalah menambah uang beredar, maka Pemerintah menempuh kebijakan kontraktif atau biasa pula dikenal sebagai kebijakan uang ketat (Al-Arif, 2010: 130-131).

Kebijakan moneter merupakan instrumen penting kebijakan publik dalam sistem ekonomi, baik modern maupun Islam. Namun perbedaan yang mendasar terletak pada tujuan dan larangan bunga dalam Islam. Syarat tercapai dan terjamin berfungsinya sistem moneter secara baik adalah otoritas moneter harus melakukan pengawasan kepada keseluruhan sistem.

Kebijakan moneter diharapkan dapat menjamin bahwa sistem moneter yang baik dapat memenuhi keperluan para penabung dan para debitur dengan cara-cara yang efisien (Abdullah, 2012: 81). Dengan demikian, tujuan penggunaan tenaga kerja penuh, dimana peningkatan pertumbuhan ekonomi akan mendorong tabungan masyarakat sebagai sumber dana lebih bagi investasi perusahaan kebijakan ini disebut kebijakan ekonomi sisi penawaran dimana pertumbuhan ekonomi dapat dicapai dengan pemberian intensif pajak bagi bisnis sehingga investasi bisnis pada perusahaan naik. Stabilitas sangat diperlukan untuk mendorong pertumbuhan ekonomi dan mengurangi kesulitan perencanaan jangka panjang (Manurung, 2009: 260)

Stabilitas tingkat harga perlu karena fluktuasi tingkat bunga dapat menciptakan ketidakpastian ekonomi dan mengakibatkan kesulitan perencanaan jangka panjang. Fluktuasi tingkat bunga mengakibatkan kesulitan konsumen untuk memutuskan apakah konsumen membeli sekarang atau masa akan datang. Bank Sentral harus mengurangi pergerakan tingkat bunga lebih tinggi untuk mendorong permintaan dana dari konsumen. 
Stabilitas pasar keuangan akan mendorong transfer dana dari investasi kurang produktif ke investasi lebih produktif, dan akhirnya mengurangi kontraksi aktivitas ekonomi. Peningkatan stabilitas pasar keuangan akan mencegah sistem keuangan dari krisis dan mendorong stabilitas tingkat bunga, asosiasi tabungan dan pinjaman, raksa dana, bank dan lembaga keuangan lainnya akan terhindar dari krisis, atau kebangkrutan.

Stabilitas nilai tukar mata uang akan mendorong perdagangan sebagai motor pertumbuhan ekonomi. Apresiasi nilai tukar mata uang secara berlebihan meningkatan daya saing industri semakin lemah, sebaliknya depresiasi berlebihan dari nilai tukar mata uang akan menciptakan inflasi yang sangat tinggi. Stabilitas nilai tukar mata uang akan memudahkan perusahaan atau individu membeli bahan baku dari luar Negeri untuk perencanaan masa datang (Manurung, 2009: 260)

Kebijakan moneter yang diformulasikan dalam sebuah perekonomian Islam, adalah menggunakan variabel cadangan uang dan bukan suku bunga. Bank Sentral harus menggunakan kebijakan moneternya untuk menghasilkan suatu pertumbuhan dalam sirkulasi uang yang mencukupi untuk membiayai pertumbuhan potensial dalam output harga yang stabil dan sasaran sosiol ekonomi lainnya. Tujuannya untuk menjamin ekspansi moneter yang pas, tidak terlalu lambat tidak juga cepat, tetapi cukup mampu menghasilkan pertumbuhan yang dapat menghasilkan kesejahteraan yang merata bagi masyarakat (Huda et-al, 2009: 170).

Dalam mendorong pertumbuhan ekonomi sekaligus stabilitas Islam tidak menggunakan instrumen bunga atau ekspansi moneter melalui percetakan uang baru atau defisit anggaran, yang dilakukan adalah mempercepat perputaran uang dan pembangunan infrastruktur sektor riil. Yang paling penting dalam setiap keuangan adalah, penentuan satuan dasar keuangan dimana satuan di nisbahkan seluruh nilai-nilai mata uang (Huda et-al, 2009: 193). Artinya kebijakan moneter bukan hanya mengutak atik suku bunga, sebab bunga memang selalu memberikan tekanan kegiatan ekonomi, maka dengan sendirinya sistem perbankan dengan bunga sangat berpengaruh terhadap bergairah atau tidaknya serta sehat tidaknya kegiatan ekonomi masyarakat. Dan secara makro sebuah tatanan ekonomi masyrakat yang ditopang dengan sistem bunga tidak akan pernah betul-betul sehat.

Islam dengan pandangan bersumber dari Allah Azza wajalla mengajarkan bahwa, memfungsikan uang hanya untuk alat tukar saja. Maka dimana ada uang beredar 


\section{6 | Hoirul Amri Analisis Kebijakan Moneter pada Awal Pemerintahan Islam terhadap Pembangunan Perekonomian Islam}

ia akan bertemu dengan barang dan jasa. Semakin banyak uang yang beredar makin banyak pula barang dan jasa diproduksi dan diserap pasar. Akibatnya, pertumbuhan ekonomi akan terus meningkat, tanpa ada kehawatiran terjadi kolaps seperti pertumbuhan ekonomi kapitalis yang siklik itu (Rivai dan Buchori, 2009: 298)

Sebagai langkah awal, Islam memiliki pandangan yang khas mengenai sistem moneter. Syaikh Abdul Qodim Zallum, dikutif Rivai dan Buchori (2009: 318) dalam bukunya Islamic Economics; Ekonomi Syari'ah bukan Opsi tapi Solusi mengatakan bahwa sistem moneter adalah sekumpulan kaedah pengadaan dan pengaturan keuangan dalam suatu negara, yang paling penting dalam setiap keuangan adalah penentuan dasar keuangan dimana kesatuan itu dinisbahkan seluruh nilai-nilai berbagai mata uang lain. Apabila satuan dasar keuangan itu adalah emas, maka sistem keuangan dinamakan sistem uang emas. Apabila satuan dasarnya perak, maka dinamakan sistem uang perak.

Syaikh Taqiyuddin an-Nabhani (2009: 298-303) mengatakan Islam telah memberikan kebebasan kepada manusia untuk melakukaan pertukaran dengan mempergunakan apa saja yang ia sukai. Hanya saja pertukaran barang dengan satuan uang tertentu itu telah ditunjukkan oleh Islam dengan satuan moneter. Islam telah menetapkan bagi kaum muslimin kepada jenis tertentu yaitu emas dan perak.

Kesimpulan ini berdasarkan beberapa alasan berikut: Pertama Islam mengharamkan menimbun (al-Kans) emas dan perak. Dalam surah at-taubah [9]: 34 larangan itu tertuju pada penimbunan emas dan perak, sebagai uang dan alat tukar. Kedua, Islam telah mengaitkan emas dan perak dengan hukum yang baku, seperti diyat dalam pembunuhan sebesar 1000 dinar dan batasan bagi potong tangan untuk pencuri atas harta yang mencapai 1/4 dinar. Ketiga, Rasulullah Saw telah menetapkan emas dan perak sebagai mata uang, dan menjadikan hanya emas dan perak sajalah sebagai standar uang. Dimana standar barang dan jasa akan dikembelikan kepada standar tersebut. Keempat, Ketika Allah SWT mewajibkan zakat uang maka Allah SWT telah mewajibkan zakat tersebut untuk emas dan perak, kemudian Allah SWT menentukan nishab zakat tersebut dengan nishab emas dan perak. Kelima, Ketika Islam menetapkan pertukaran uang (Sharf), Islam menetapkan uang dalam bentuk emas dan perak. Sharf adalah menukarkan atau membeli uang dengan uang, baik dalam jenis yang sama seperti emas dengan emas atau perak dengan perak, atau antar jenis yang berbeda seperti membeli emas dengan perak 
Berkaitan dengan instrumen kebijakan moneter ada beberapa teori permintaan akan uang, Islam mengelompokan ke dalam tiga kelompok mazhab :

1. Mazhab pertama. Iqtishōduna, pendukung mazhab ini antara lain Dr. Kadin Sard, Dr. Bagir al Hasani dan Dr. Abas Murakhor, mazhab ini memandang bahwa jumlah uang yang beredar merupakan elastis sempurna, dimana pemerintah sebagai pemegang otoritas moneter tidak mampu untuk memenuhi jumlah uang yang beredar (Karim 2010: 198). Pada awal pemerintahan Islam dimana mata uang yang beredar adalah dinar dan dirham yang diimpor dari Roma dan Persia, dimana nilai tukar pada saat itu yang berlaku adalah satu dinar sebanding dengan sepuluh dirham.

2. Mazhab kedua. Mainsterm. Dikatakan Metwally dikutip Karim (2010: 201), bahwa penawaran uang dalam Islam sepenuhnya dikontrol oleh negara sebagai pemegang monopoli dari penerbitan uang yang syah (Legal Tender). Keberada Baitul Mall semasa awal pemerintahan Islam merupakan prototype dari bank sentral yang selama ini. Keberadaan bank sentral untuk menerbitkan mata uang dan menjaga nilai tukar agar dapat berada pada tingkat harga yang stabil. Negara melakukan sendiri kontrol terhadap penerbitan uang dan kepemilikan atas semua bentuk uang baik logam, kertas atau kredit.

3. Mazhab ketiga. Mazhab alternatif. Menurut mazhab ini, permintaan uang terkait erat dengan Konsep Endogeneus uang dalam Islam. Konsep ini dalam Islam diartikan sebagai refresentatif dari volume transaksi yang ada dalam sektor riil. Konsep ini menjembatani dan tidak mendikotomi antara pertumbuhan uang disektor meneter dan sektor riil (Mahmud dan Rukmana, 2010: 46)

Dengan demikian kebijakan moneter yang dikelola dengan baik akan menghasilkan tingkat perekonomian yang stabil melalui mekanisme transmisi pada harga dan output yang pada akhirnya membawa dampak pada variabel-variabel lain seperti tenaga kerja dan pendapatan negara. Sektor moneter merupakan jaringan dan mempengaruhi sektor ekonomi riil.

\section{B. Analisis Kebijakan Moneter Pada Awal Pemerintahan Islam Terhadap Pertumbuhan Perekonomian Islam}

Kondisi moneter bangsa Arab pada awal Pemerintahan Islam menggunakan standar mata uang Dinar emas Hercules, Bizantium dan Dirham perak Dinasti Sasanit 


\section{8 | Hoirul Amri Analisis Kebijakan Moneter pada Awal Pemerintahan Islam terhadap Pembangunan Perekonomian Islam}

dari Irak dan sebagian mata uang bangsa Himyar Yaman. Tatkala Rasulullah SAW dianggkat sebagai Nabi dan Rasul Allah SWT, beliau menetapkan sistem moneter tersebut apa yang sudah menjadi tradisi penduduk Makkah, dan beliau juga memerintahkan penduduk Madinah untuk mengikuti ukuran timbangan penduduk Makkah ketika bertransaksi ekonomi menggunkan Dirham dalam jumlah bilangan bukan ukuran timbangan.

Disamping itu, pada awal Pemerintahnya, Pemerintah Islam mengakui berbagai transaksi muamalah yang menggunakan Dinar Romawi dan Dirham Persia, Pemerintah juga mengakui standar timbangan yang berlaku dikalangan kaum Quraisy untuk menimbang berat Dinar dan dan Dirham. Sehubungan dengan hal ini, kaum muslimim terus menggunakan Dinar Romawi dan Dirham Persia dalam bentuk cap, dan gambar aslinya sepanjang hidup Rasulullah SAW dan dilanjutkan pada awal kekhalifahan Abu Bakar Siddiq r.a dan ke khalifahan Umar bin Khattab r.a.

Sebagai lazimnya sebuah negara yang baru berdiri, negara Madinah tidak terlepas dari persoalan-persoalan ekonomi dan moneter. Persoalan ekonomi dan moneter yang paling besar dihadapi Pemerintah pada periode awal adalah menghadapi embargo ekonomi dan moneter dari bangsa Quraisy dan sekutu-sekutunya. Disisi lain jumlah penduduk yang semakin bertambah karena semakin banyaknya kaum Muhajirin yang datang ke Madinah. Sementara perekonomian Madinah dikuasai kaum Yahudi yang terkenal mahir dalam melakukan aktivitas perekonomian (Antonio 2007: 163).

Hal utama yang dilakukan awal Pemerintah Islam adalah berusaha sekuat tenaga untuk memantapkan Negara Islam yang baru saja terbentuk di Madinah dengan cara membuat kesepakatan bersama dengan seluruh komponen penduduk yang kelak dikenal dengan Piagam Madinah. Dibidang ekonomi dan moneter, salah satu tujuan dibuatnya kesepakatan ini adalah untuk melindungi segenap warga Negara dari eksploitasi kekuatan non muslim terutama komonitas Yahudi dan memapankan tatanan ekonomi dan moneter kaum muslimin dari kezaliman dan ketidak adilan (Hoetoro, 2007: 92).

Ada beberapa kebijakan ekonomi Pemerintah yang digambarkan secara ringkas diantaranya melarang riba, gharar, ikhtikar, tadlis dan market ineffisiensi. Merujuk kepada pengertian riba al-Qur'an memakai kata riba untuk bunga. Ibnu Hajar alAskolani mengatakan esensi riba adalah kelebihan apakah itu berupa barang ataupun uang, seperti uang dua Dinar sebagai pengganti uang satu Dinar. Menurut Abu Bakar 
Ibnu al-Arabi setiap kelebihan yang tidak ada sesuatupun dikemblikan sebagai pengantinya, menurut mujahid unsur riba terdapat dalam setiap bentuk transaksi pada masa pra Islam, setiap kali seseorang mengadakan perjanjian pinjaman ia akan meminta pada kriditornya untuk memberikan jangka waktu pembayaran yang panjang dan berjanji akan mengembalikan padanya dengan sejumlah kelebihan yang ditentukan dari uang pokok yang dipinjamkan (Rahman, 1997: 310)

Awal Pemerintah Islam menetapkan kebijakan pada setiap pedagang untuk senantiasa berpegang pada sipat-sipat terpuji. Hal ini bukan saja menguntungkan perdangannya sendiri, akan tetapi tidak punya konsekuensi regelius. Rasulullah SAW berkata "Pedagang yang Jujur dan Amanah akan berada disyurga bersama Nabi, syuhadah, dan orang-orang Shaleh“. Rasulullah SAW sendiri mepraktekkan sendiri ketika beliau berada di Makkah, ketika membawa komoditi perdagangan kepunyaan Siti Khadijah r.a, seorang pengusaha wanita yang kemudian tertarik akan kejujuran beliau dengan menikahinya. Dengan bekal kejujuran beliau, dagangan itu laku keras ditengah persaingan Throat-To Throat Competition di okaz secara wajar. Selain itu Rasulullah SAW juga mengajarkan agar para pedangang senantias bersikap adil, baik (Ihsan), kerjasama (Ta'awun), amanah, tawakkal, qona'ah, sabar dan tabah. Sebaliknya Rasulluah SAW menasehati agar meninggalkan sipat kotor perdagangan yang hanya memberikan keuntungan sesaat tetapi merugikan diri sendiri didunia dan akherat. Akibatnya kredebilitas hilang, pelanggan lari dan kesempatan berikutnya jadi sempit. Sipat-sipat yang dimaksud adalah zhalim, menipu, suka marah, benci, terlalu memuja uang tidak memperdulikan hukum dan hutang yang berlebihan (Muhammad, 2004: 8).

Awal Pemerintah Islam telah mengenal sistem moneter walaupun saat itu belum terlalu diperlukan. Syaikh Abdul Qadim Zallum dalam kitab Amwal Daulati al-Khilafah dikutip Rivai'dan Buchori (2009: 9) mengatakan bahwa sistem moneter adalah sekumpulan kaedah pengadaan dan pengaturan keuangan dalam suatu negara. Yang paling penting dalam setiap keuangan adalah penentuan satuan dasar keungan dimana kepada satuan itu dinisbahkan seluruh niali berbagai mata uang lain. Apabila satuan dasar keuangan adalah emas, maka sistem keuangannya dianmakan uang emas, apabila satuan dasar perak, dinamakan sistem uang perak. Apabila satuan dasar terdiri atas dua satuan mata uang (emas dan perak) dinamakan sistem dwi logam. Dan apabila nilai satuan mata uang tidak dihubungkan secara tetap dengan emas atau perak (baik terbuat 


\section{Hoirul Amri Analisis Kebijakan Moneter pada Awal Pemerintahan Islam terhadap Pembangunan Perekonomian Islam}

dari logam lain seperti tembaga atau dibuat dari kertas), sistem keuangannya disebut Fiat Money.

Pada awal Pemerintahan Islam, pemerintah telah menetapkan kebijakan keuangan bahwa emas dan perak sebagai setandar moneter. Pemerintah menjadikan hanya emas dan perak sebagai setandar keuangan (moneter) untuk mengukur standar nilai barang dan jasa. Dengan kedua mata uang emas dan perak inilah semua transaksi dilangsungkan. Kemudian Pemerintah juga telah membuat kebijakan untuk standar moneter ini dalam bentuk Uqiyah, Dirham, Mitsqol, Mitsqol merupakan berat pokok yang sudah diketahui umum, yaitu setara dengan 22 qirath kurang dari satu habbah dan Dinar. Semua bentuk ini sudah dikenal dengan sangat mashur pada awal Pemerintahan Islam, ketika itu juga masyarakat Arab telah memepergunakannya sebagai alat dan ukuran nilai dalam transaksi (Hidayat, 2010: 146)

Islam juga telah mengaitkan emas dan perak dengan hukum-hukum tertentu, ketika Islam mewajibkan diyat, Islam telah menentukannya dengan ukuran emas, Rasulullah SAW pernah menyatakan dalam surat beliau yang dikirim kepada penduduk Yaman bahwa di dalam pembunuhan jiwa trerdapat diyat berupa 100 ekor onta dan terhadap pemilik emas ada kewajiban sebanyak 1000 Dinar (HR an-Nasai) ketika Islam mewajibkan hukum potong tangan bagi pelaku pencurian Islam juga menentukan ukuran tertentu dalam bentuk emas, Rasulullah SAW bersabda " Tangan wajib dipotong apabila mencuri 1/4 Dinar atau lebih (HR al-Bukhari dari Aisyah).

Ketentuan hukum Islam diatas menunjukkan bahwa Dinar, Dirham dan mitsqol merupakan satuan uang yang digunakan untuk mengukur (menghitung) nilai barang dan jasa. Jadi satuan Dinar dan Dirham inilah yang menjadi uang yang berpungsi sebagai ukuran harga barang sekaligus sebagai alat ukur. Nilai tukar atau alat ukur yang berlaku saat itu adalah satu Dinar sebanding dengan sepuluh Dirham. Banyak rendahnya permintaan akan Dinar atau Dirham tergantung dari perdagangan barang dengan luar negeri. Jika permintaan akan uang naik, maka Dinar akan diimport dengan cara pasar melakukan eksport barang ke Romawi (untuk mendapatkan Dinar) atau ke Persia (untuk mendapatkan Dirham). Namun jika permintaan uang turun import barang dari luar negerilah yang akan dilakukan.

Pada masa ini tidak dikenal dan memang pemerintah mengeluarkan kebijakan untuk melarang pengenaan bea masuk pada barang import maupun uang import, 
sehingga permintaan uang internal akan selalu dapat tercukupi. Disamping itu, karena nilai emas dan perak pada kepingan Dinar dan Dirham sama dengan nilai nominal (Face Value) maka uangnya memungkinkan adanya peleburan kepingan uang menjadi barangbarang hiasan yang secara otomatis akan menarik uang beredar dari pasar (Karim, 2010: 199).

Selain menggunakan mata uang Dinar dan Dirham, alat pembayaran yang digunakan pada awal pemerintahan Islam adalah sistem kredit, kredit selain memiliki kelebihan yang dimiliki Dirham dan Dinar sebagai alat pembayaran, kredit memiliki keuntungan lain misalnya untuk melakukan transaksi yang nilainya cukup tinggi tentu dibutuhkan uang yang sebagai alat pembayaran. Tentu ini tidak praktis karena itu berat volume yang dimiliki uang itu mengurangi daya tarik sebagai media pertukaran, tambah lagi mungkin juga terjadi pada saat transaksi pembeli tidak dapat menyediakan Dirham dan Dinar secara mudah dan cepat.

Pada awal pemerintahan Islam defisit anggaran jarang terjadi dan sistem pengelolaan moneter diserahkan kepada Baitul Mal. Baitul Mal adalah pos yang dikhususkan untuk mengelola semua pemasukan atau pengeluaran harta yang menjadi hak kaum muslimin. Setiap harta yang menjadi hak kaum muslimin, sementara pemiliknya tidak jelas maka harta tersebut merupakan hak Baitul Mal, bahkan kadang pemiliknya jelas sekalipun. Apabila harta itu telah diambil, maka dengan pengambilan tersebut harta tadi telah menjadi hak Baitul Mal, baik harta itu dimasukkan kedalam kasnya ataupun tidak. Karena Baitul Mal ini mencerminkan post bukan tempat (anNabhani 2009: 253).

Di dalam pengelolaan moneter, awal Pemerintah Islam mengalokasikan dana untuk pemyebaran Islam, pendidikan dan kebudayaan, pengembangan ilmu pengetahuan, pengembangan inprastruktur, dan penyediaan layanan kesejahteraan sosial. Seluruh alokasi dana Baitul Mal tersebut mempunyai dampak terhadap pertumbuhan ekonomi baik secara langsung atau tidak, seperti alokasi untuk penyebaran Islam yang berdampak terhadap kenaikan Agregate Demaand sekaligus Agregate Supply karena populasi akan meningkat dan penggunaan sumberdaya alam semakin maksimal. Dalam hal tersebut adalah peristiwa hijrahnya kaum Muhajirin ke Madinah dan persaudaraannya dengan kaum Anshar. Selain itu penyebaran Islam ini juga akan dapat meningkatkan pendapatan Baitul Mal. 


\section{2 | Hoirul Amri Analisis Kebijakan Moneter pada Awal Pemerintahan Islam terhadap \\ Pembangunan Perekonomian Islam}

Dengan meningkatnya pendapatan masyarakat, tidak berarti bahwa Marginal Propensity to Consume akan meningkat pula. Berdasarkan sebuah penelitian, peningkatan pendapatan masyarakat justru berpengaruh terhadap kenaikan Marginal Propensity to Save. Karena pemerintah awal Islam sangat mendorong masyarakat agar melakukan investasi, akibatnya dalam jangka panjang, hal tersebut akan meningkatkan pula pendapatan nasional secara keseluruhan (Amalia, 2010: 79).

Menurut Karim (2010: 153) pemerintah menerapkan beberapa kebijakan didalam mengelola sistem moneter, anggaran pendapatan dan belanja Negera untuk keperluan Negera. Pertama, langkah yang ditempuh Pemerintah adalah meminta bantuan kaum muslimin secara suka rela untuk memenuhi kebutuhan pasukaan muslim. Kedua, meminjam peralatan dari kaum non muslim secara cuma-cuma dengan jaminan pengembalian dan ganti rugi bila terjadi kerusakan. Hal ini biasanya merupakan klausul dari suatu perjanjian damai antara Pemerintan dengan susku-suku non muslim.

Ketiga, yang dilakukan pemerintah adalah meminjam uang dari orang-orang tertentu untuk diberikan kepada para muallaf, pinjaman dialakukan dalam jangka pendek. Setelah perang hunain dan setelah harta rampasan perang tersebut dibagikan, seluruh utang-utang dilunasi. Bilal diperintahkan Rasulullah SAW membantu orangorang yang membutuhkan dan melunasi uang orang yang tidak dapat membayar utangnya sendiri. Bilal dibenarkan meminjam uang untuk memenuhi kebutuhan pengeluaran tersebut jika dibutuhkan.

Keempat, yang ditempuh oleh Rasulullah SAW adalah menerapkan lebijakan intensif untuk menjaga pengeluaran dan meningkatkan pertisipasi kerja dan produksi kaum muslimin. Kebijakan ini adalah menghargai orang yang bekerja, beraktivitas, serta menafkahi keluarga dan praktis mencela para pengangguran. Selain itu, perbuatan baik seperti pemberian qord hasan, wakaf, sedekah menghasilkan redistribusi pendapatan dan meningkatkan effisiensi pertukaran serta permintaan total. Pengharaman monopoli, riba, transaksi kali bikali, dan transaksi-transaksi lainnya termasuk kecaman terhadap sikap hidup boros, selain meningkatkan effisiensi sektor swasta, juga meningkatkan penawaran total serta kesejahteraan ekonomi secara umum.

Peran awal Pemerintah Islam dalam membangun perekonomian mengindikasikan bahwa Negara memiliki hak dan wewenang untuk membangun ekonomi rakyatnya, demi tumbuhnya perekonomian masyarakat banyak dan mengawasi 
aktivitas ekonomi tersebut agar tidak menyimpang dari Syari'at Islam. Dlam hal ini berarti dalam Islam Pemerintah mempunyai hak untuk melibatkan diri dalam perekonomian masyarakatnya. Bahkan hal tersebut merupakan salah satu kewajiban yang dimilikinya untuk mewujutkan dan memelihara kesejahteraan sosial umat. Seperti pada pase Madinah seiring dengan telah diperolehnya kekuasaan politik Nabi Muhammad SAW, maka beliau mengarahkan pembangunan sistem ekonomi yang Islami dan merombak semua sistem dan peraktek ekonomi yang bertentangan dengan nilai-nilai Islam, sekaligus melakukan penerapan dan pengawasan secara langsung dalam kehidupan masyarakat sehari-hari. Dalam hal ini bilamana terdapat penomena yang menyimpang dari nilai-nilai ajaran Islam di Madinah maka Nabi SAW memberikan reaksi dan teguran secara langsung (Muftifiandi, 2004: 7)

Menurut Karim (2010: 27) setelah melakukan berbagai upaya stabilisasi dibidang sosial, politik serta pertahanan negara pemerintah melakukan dasar-dasar dan sistem keungangan negara sesuai dengan ketentuan al-Qur'an. Seluruh paradigma berpikir dibidang ekonomi serta aflikasinya dalam kehidupan sehari-hari yang tidak sesuai dengan ajaran Islam dihapus dan digantikan dengan paradigma baru yang sesuai dengan nilai-nilai al-Qur'an yakni persamaan, persaudaraan, kebebasan, dan keadilan. Prinsip-prinsip kebijakan dalam pembangunan ekonomi yang digariskan al-Qur'an adalah. a) Allah adalah penguasa tertingi sekalius pemilik absolut seluruh alam semesta. b) Manusia adalah Khalifah Allah SWT dimuka bumi bukan milik sebenarnya. c) Semua yang dimiliki dan didapatkan manusia adalah dengan seizin Allah SWT, oleh karena itu manusia yang kurang beruntung mempunyai hak atas sebagian kekayaan yang dimiliki manusia lain yang lebih beruntung. d) Kekayaan harus diputar dan tidak boleh ditimbun. e) Eksploitasi ekonomi dengan segala bentuknya termasuk riba, harus dihilangkan. f) menerapkan sistem warisan sebagai media retrebusi kekayaan. g) Menerapkan kewajiban bagi seluruh individu termasuk orag-orang miskin (Amalia 2010: 77)

Dengan adanya berbagai kebijakan tersebut sangat berdampak pada peningkatan produksi dan jasa dalam perekonomian yang akhirnya, membawa kepada tingginya tingkat keseimbangan penawaran dan permintaan Agregate. Seiring dengan kemajuan dibidang ekonomi, kesejahteraan dan ketenagakerjaan kaum muslimin itu terus meningkat. Dengan demikian kebijakan moneter dan fislkal meskipun melalui 


\section{4 | Hoirul Amri Analisis Kebijakan Moneter pada Awal Pemerintahan Islam terhadap Pembangunan Perekonomian Islam}

perluasan, tidak menimbulkan pengaruh buruk terhadap nilai uang (Amalia, 2010: 85). Karena itu dapat disimpulkan bahwa pada awal Pemerintahan Islam penawaran uang (Money Sufly) terhadap pendapatan sangat elestis (lentur, lues) (Karim, 2010: 163).

Di atas semua itu, awal Pemerintah Islam melalui kebijakan khususnya berusaha meningkatkan permintaan transaksi terhadap uang. Meskipun demikian penawaran uang tetap elastis. Hal ini karena tidak ada hambatan terhadap import ketika permintaan naik. Di lain pihak, ketika penawaran naik Eecess Supply (penawaran berlebih) akan diubah menjadi ornamen emas dan perak . Dampaknya tidak ada penawaran atau permintaan berlebih dan pasar akan tetap berada pada keseimbangan (Equibilibrium). Oleh karena itu, nilai uang akan akan selalu tetap stabil (Karim, 2010: 166).

\section{SIMPULAN}

Dari berbagai penjelasan di atas dapat disimpulkan sebagai berikut: Pertama, peletakan dasar-dasar sistem keuangan (Moneter) Negara yang dilakukan oleh awal Pemerintahan Islam merupakan langkah-langkah yang sangat signifikan, sekaligus brilian dan spektakuler pada masa itu sehingga Islam sebagai Agama dan Negara dapat berkembang pesat dalam jangka waktu yang relatif singkat. Sistem ekonomi dan moneter yang diterapkan oleh Rasulullah SAW berakar dari prinsip-prinsip al-Qur'an yang merupakan sumber utama ajaran Islam. Sebagai pedoman utama bagi manusia dalam melakukan aktivitas ekonomi dan moneter disetiap aspek kehidupan.

Kedua, pengelolaan sistem moneter pada awal Pemerintahan Islam diserahkan kepada lembaga Baitul Mal. Seluruh alokasi dana Baitul Mal tersebut mempunyai dampak terhadap pertumbuhan ekonomi baik secara langsung maupun tidak, seperti alokasi untuk penyebaran Islam berdampak terhadap kenaikan Agregate Demand sekaligus Agregate Supply. Karena populasi akan meningkat dan penggunaan sumber daya alam semakin maksimal.

Ketiga, dampak kebijakan moneter tehadap perekonomian pada awal Pemerintahan Islam terlihat dengan meningkatnya permintaan Agregate Demand masyarakat setelah hijrah ke Madinah dengan mempersaudarakan muhajirin dan anshar. Dengan adanya persaudaraan ini menempatkan setiap anshar bertanggung jawab terhadap muhajirin sehingga distribusi pendapatan dari anshar ke muhajirin meningkat dan berdampak pada pada peningkatan permintaan total masyarakat .dan menghasilkan 
peningkatan sumber daya, tenaga kerja, lahan dan modal. Disamping itu untuk melahirkan kekuatan ekonomi dan moneter awal Pemerintah Islam mengeluarkan kebijakan dengan melakukan sinergi dan integrasi potensi umat Islam. Pemerintah integrasikan suku aus dan hajraj serta muhajirin dan anshar dalam bingkai ukhwah yang kokoh untuk membangun kekuatan ekonomi dan moneter.

\section{DAFTAR PUSTAKA}

Abdullah, Boedi 2010. Peradaban Pemikiran Ekonomi Islam, Bandung: Pustaka Setia.

Ali, Muhammad tt. Kamus Lengkap Bahasa Indonesia Modern, Jakarta: Amani.

Amalia, Euis 2010. Sejarah Pemikiran Ekonomi Islam Dari Masa Klasik Hingga Kontemporer, Yogyakarta: Gramata Publishing.

Antonio, Muhammad Syafi'i, 2007. Muhammad Saw The Super Leader Super Manager Jakarta: Tazkia Multimedia \& ProLM centre Jakarta.

Arif, M Nur Rianto 2010. Teori Makro Ekonomi Islam, Konsep Teori Dan Analisis. Bandung: Al-Fabeta Bandung.

Boediono, 1990. Seri Sinopsis Pengantar Ilmu Ekonomi no 2 Ekonomi Makro, Yogyakarta: BPFE Yokyakarta.

Chapra, M. Umar 2000. Islam Dan Pembangunan Ekonomi, Bandung: Gema Insani Press.

Hidayat, Muhammad 2010 An Introduction To The Syari'ah Economic Pengantar Ekonomi Syari'ah, Jakarta: Zikrul Hakim.

Hoetoro, Arief 2007 Ekonomi Islam Pengantar Analisis Kesejarahan Dan Methodologi, Malang: BPFE Universitsas Brawijaya.

Huda, Nurul, dkk, 2009. Ekonomi Makro Islam, Pendekatan Teoritis, Jakarta: Kencana Prenada Media Group

Karim, Adiwarman A, 2010, Ekonomi Mikro Islam, Yogyakarta: Book Publisher.

Mahmud, Amir dan Rukmana 2010, Bank Syari'ah Teori, Kebijakan, Dan Study Impiris di Indonesia, Jakarta: Pratama Erlangga.

Manan, Muhammad Abdul, 1997. Islam Economic Theory And Practice, Terjemahan Paton Arif Harahap Yogyakarta: Dana Bakti Primayasa.

Manurung, Jonni 2009, Ekonomi Keuangan Dan Kebijakan Moneter, Salemba Empat, Jakarta. 
16| Hoirul Amri

Analisis Kebijakan Moneter pada Awal Pemerintahan Islam terhadap

Pembangunan Perekonomian Islam

Muftifiandi, 2004, Praktek Ekonomi pada masa Rsulullah Saw Dan Kaitannya Dengan Prektek Ekonomi Islam Dewasa ini Tesis program Pasca Sarjana Imam Bonjol, Padang.

Muhammad, 2004. Dasar-dasar keuangan Islam, Yogyakarta: Ekonesia.

Muhammad, 2007. Prinsip-prinsip Ekonomi Islam, Jakarta: Graha Ilmu.

Nurnasrina, 2013, "Ekonomi Islam Sarana dalam Mewujudkan Ekonomi Masyarakat Madani”, dalam Jurnal Hukum Islam, Vol. XIII No. 1 Nopember 2013.

Rahman, Afzalur 1997. Muhammad as A Trade Muhammad Terjemahan Dewi Nurjulianti dan Isnan dkk, Jakarta: Yayasan Swarna Bumi.

Rivai, Veithzal dan Buchori, 2009. Islamic Economics Syari'ah Bukan Ofsi Tapi Solusi, Jakarta: Bumi Aksara.

Shihab, M.Quraish 2007. Membumikan al-Qur'an. Bandung: Mizan.

Sinn, Abu Ahmad Ibrahim 2008. Manajeman Syariah Sebuah Kajian Historis Dan Kontemporer. Terj. Al-idarah fiqh Islam. Oleh Dimayauddin Djuaini. Jakarta : Raja Grafindo Persada. 